\title{
Use of a crosslinked casein micelle hydrogel as a carrier for jaboticaba (Myrciaria cauliflora) extract
}

\begin{abstract}
Lima Nascimento, Luis Gustavo; Casanova, Federico; Nogueira Silva, Naaman Francisco; Novaes de Carvalho Teixeira, Álvaro Viana; Peres de Sá Peixoto Júnior, Paulo; Teixeira Ribeiro Vidigal, Márcia Cristina; Stringheta, Paulo Cesar; Fernandes de Carvalho, Antônio
\end{abstract}

Published in:

Food Hydrocolloids

Link to article, DOI:

10.1016/j.foodhyd.2020.105872

Publication date:

2020

Document Version

Peer reviewed version

Link back to DTU Orbit

Citation (APA):

Lima Nascimento, L. G., Casanova, F., Nogueira Silva, N. F., Novaes de Carvalho Teixeira, Á. V., Peres de Sá Peixoto Júnior, P., Teixeira Ribeiro Vidigal, M. C., Stringheta, P. C., \& Fernandes de Carvalho, A. (2020). Use of a crosslinked casein micelle hydrogel as a carrier for jaboticaba (Myrciaria cauliflora) extract. Food Hydrocolloids, 106, [105872]. https://doi.org/10.1016/j.foodhyd.2020.105872

\section{General rights}

Copyright and moral rights for the publications made accessible in the public portal are retained by the authors and/or other copyright owners and it is a condition of accessing publications that users recognise and abide by the legal requirements associated with these rights.

- Users may download and print one copy of any publication from the public portal for the purpose of private study or research.

- You may not further distribute the material or use it for any profit-making activity or commercial gain

- You may freely distribute the URL identifying the publication in the public portal 


\section{Journal Pre-proof}

Use of a crosslinked casein micelle hydrogel as a carrier for jaboticaba (Myrciaria cauliflora) extract

Luis Gustavo Lima Nascimento, Federico Casanova, Naaman Francisco Nogueira Silva, Álvaro Viana Novaes de Carvalho Teixeira, Paulo Peres de Sá Peixoto Júnior, Hydrocolloids Márcia Cristina Teixeira Ribeiro Vidigal, Paulo Cesar Stringheta, Antônio Fernandes de Carvalho

PII: S0268-005X(19)32390-2

DOI: https://doi.org/10.1016/j.foodhyd.2020.105872

Reference: FOOHYD 105872

To appear in: Food Hydrocolloids

Received Date: 11 October 2019

Revised Date: 13 February 2020

Accepted Date: 18 March 2020

Please cite this article as: Lima Nascimento, L.G., Casanova, F., Nogueira Silva, N.F., Novaes de Carvalho Teixeira, Á.Viana., Peres de Sá Peixoto Júnior, P., Teixeira Ribeiro Vidigal, Má.Cristina., Stringheta, P.C., Fernandes de Carvalho, Antô., Use of a crosslinked casein micelle hydrogel as a carrier for jaboticaba (Myrciaria cauliflora) extract, Food Hydrocolloids (2020), doi: https:// doi.org/10.1016/j.foodhyd.2020.105872.

This is a PDF file of an article that has undergone enhancements after acceptance, such as the addition of a cover page and metadata, and formatting for readability, but it is not yet the definitive version of record. This version will undergo additional copyediting, typesetting and review before it is published in its final form, but we are providing this version to give early visibility of the article. Please note that, during the production process, errors may be discovered which could affect the content, and all legal disclaimers that apply to the journal pertain.

() 2020 Published by Elsevier Ltd. 


\section{Journal Pre-proof}

\section{Author statement}

Luis Gustavo Lima Nascimento: Investigation, Methodology, Writing Original Draft. Federico Casanova: Conceptualization, Methodology, Writing - Original Draft, Project administration. Naaman Francisco Nogueira Silva: Conceptualization, Methodology, Writing - Original Draft, Project administration. Álvaro Viana Novaes de Carvalho Teixeira: Formal analysis. Paulo Peres de Sá Peixoto Júnior: Formal analysis, Supervision. Márcia Cristina Teixeira Ribeiro Vidigal: Investigation. Paulo Cesar Stringheta: Resources. Antônio Fernandes de Carvalho:

Conceptualization, Validation, Resources, Writing - Original Draft and Funding acquisition. 
pH 6.7

\section{Casein suspension}

pH 4.5

\section{Casein hydrogel}
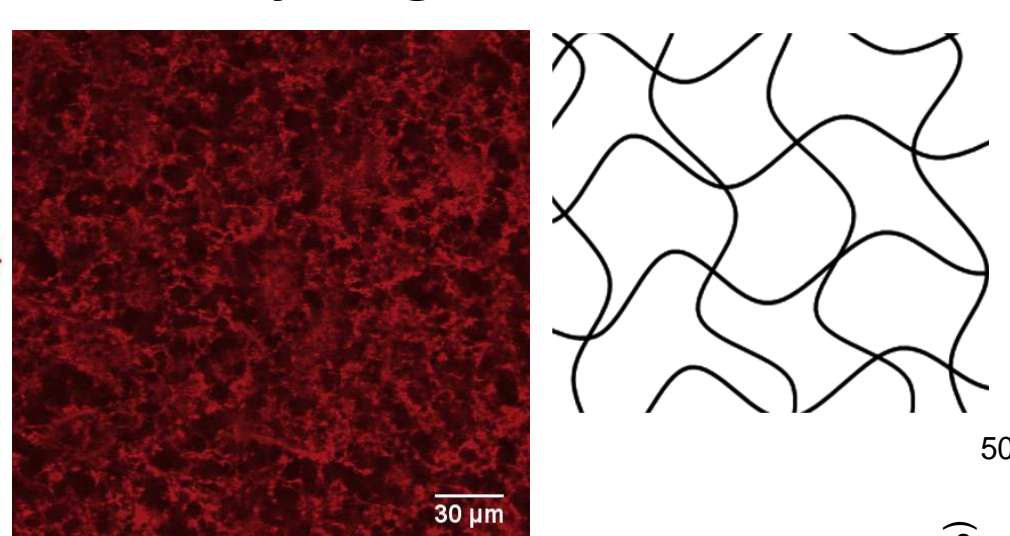

JCE release profile

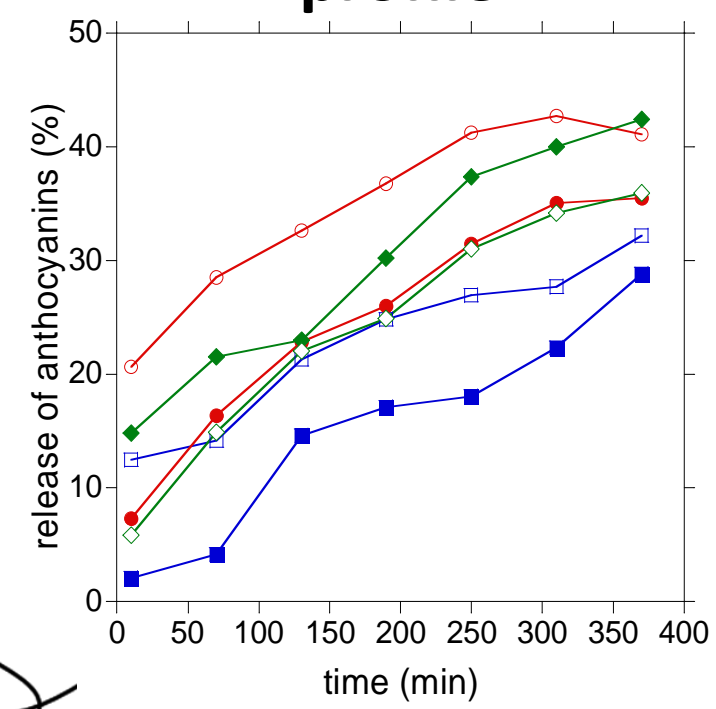

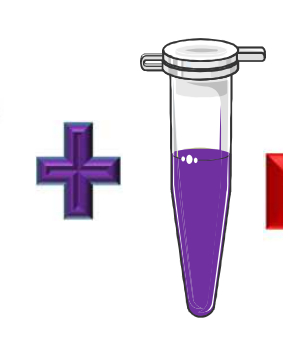

Glucono- $\delta$-lactone

Jaboticaba crude extract (JCE)

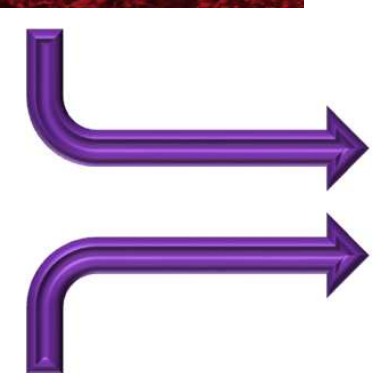

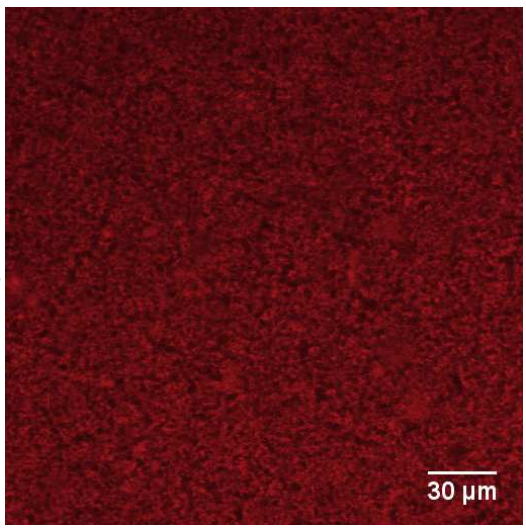

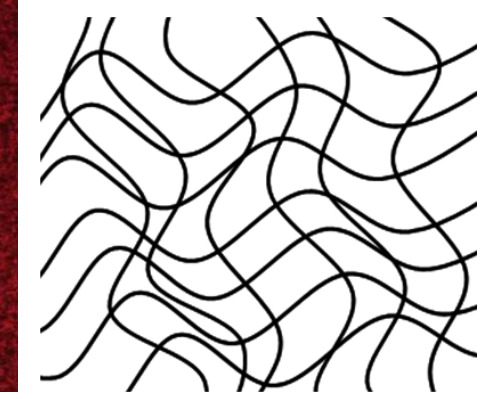


1

2

3

4 Luis Gustavo Lima Nascimento a, Federico Casanova ${ }^{\text {b }}$, Naaman Francisco

5 Nogueira Silva ${ }^{c}$, Álvaro Viana Novaes de Carvalho Teixeira ${ }^{d}$, Paulo Peres de

6 Sá Peixoto Júnior e Márcia Cristina Teixeira Ribeiro Vidigal a, Paulo Cesar

7 Stringheta ${ }^{a}$, Antônio Fernandes de Carvalho ${ }^{a^{*}}$.

8 a Departamento de Tecnologia de Alimentos, Universidade Federal de Viçosa

9 (UFV), 36570-900 Viçosa, Minas Gerais, Brazil.

10

${ }^{b}$ Food Production Engineering, DTU Food, Technical University of Denmark, Søltofts Plads227, Dk-2800 Lyngby, Denmark.

${ }^{c}$ Centre of Natural Sciences, Universidade Federal de São Carlos (UFSCar), Buri, SP, 18290-000, Brazil.

d Departamento de Física, Universidade Federal de Viçosa (UFV), 36570-900 Viçosa, Minas Gerais, Brazil.

e Laboratoire de Processus aux Interfaces et Hygiène des Matériaux, INRA, Villeneuve d'Ascq, France.

* Corresponding author

Tel: (+55) - 31 - $3899-1800$

E-mail address: antoniofernandes@ufv.br 


\section{Abstract}

28 Casein micelle hydrogels were developed using transglutaminase (Tgase) as a crosslink agent in order to encapsulate anthocyanins from jaboticaba fruit (Myrciaria cauliflora). Spray dried casein micelles (CMs) powder was rehydrated in ultrapure water at a concentration of $4.5 \% \mathrm{w} / \mathrm{w}$, and Tgase was added at 3 units/g of casein. The suspensions were incubated at $45^{\circ} \mathrm{C}$ for $1 \mathrm{~h}$, followed by enzyme deactivation at $85^{\circ} \mathrm{C}$ for $5 \mathrm{~min}$. Jaboticaba extract (JE), obtained from jaboticaba peel, was added to the suspensions at a concentration of $2 \%(w / w)$ at $25^{\circ} \mathrm{C}$. In the suspensions, Tgase promoted a reduction in CMs size and an increase in the degree of casein polymerization. The presence of JE did not affect CMs size or charge. The hydrogel samples were produced by acidification of the suspensions using $2 \% \mathrm{w} / \mathrm{w}$ of glucono - $\delta$ - lactone until $\mathrm{pH}$ 4.5 at $30{ }^{\circ} \mathrm{C}$. The hydrogels were analyzed using small deformation rheology and confocal laser scanning microscopy. Tgase treatment promoted the formation of a more compact protein matrix compared to the samples without the enzyme. The presence of JE decreased hydrogel elasticity and increased hydrogel pore size. The JE release profile was evaluated by immersing the hydrogels in three buffer solutions at $\mathrm{pH} 2.0,4.5$ and 7.0. The release rates for the hydrogels with Tgase were lower for all $\mathrm{pH}$ values. Solutions with higher $\mathrm{pH}$ values induced faster release rates. These findings can be applied to specific delivery systems, such as the transport of JE in an intestinal environment.

Keywords: casein micelles, hydrogel, transglutaminase, Jaboticaca crude extract, anthocyanins, release profile. 


\section{Introduction}

Jaboticaba is a fruit that is high in polyphenols with elevated levels of anthocyanins, especially in the peel (De Castro, Da Silva, De Oliveira, Desobry, \& Humeau, 2014). Several studies reviewed by Smeriglio, Barreca, Bellocco \& Trobetta (2016) attribute health characteristics to anthocyanins which include reduced risk of heart disease, stroke, cancer, and obesity. There are several methods for extracting anthocyanins from jaboticaba peel these include use of acidified ethanol, acidified methanol, ultrasounds, supercritical fluids, pressurized liquid and microwave exposure (Silva, Costa, Calhau, Morais, \& Pintado, 2017). The potential applications for anthocyanins in enriched food systems and biomedical applications is limited by the anthocyanins' susceptibility to degradation. Anthocyanins are sensitive to light, oxygen, temperature and $\mathrm{pH}$ changes (Moura, Cunha, Alezandro, \& Genovese, 2018). Therefore, techniques that can protect and maintain the anthocyanins' ability to resist destabilizing conditions are essential for future applications.

Hydrogels are defined as three-dimensional networks that can entrap high volumes of water in their structures (Klement, Lord, \& Parker, 1960). Hydrogels can be classified into many categories according to source, polymeric composition, configuration, crosslink type, network electrical charge and physical appearance (Ahmed, 2015). Use of hydrogel systems in biomedical applications such as tissue engineering, delivery systems and absorption materials has been studied over the years (Ahmed, 2015; Caló \& Khutoryanskiy, 2015). Hydrogels can be made from a wide range of polymers, such as proteins (Khodaverdi, Maftouhian, Aliabadi, \& Hassanzadeh, 2018; Li, Fu, \& Zhang, 2014; Loewen, Chan, \& Li-chan, 2018), carbohydrates (Bera \& Dutta, 2017) and polymer combinations (Ozel, Cikrikci, Aydin, \& Oztop, 2017; Zhang, Decker, \& McClements, 2014; Ma et al., 2016; Xu, Fan, Duan, \& Gao, 2018). Polymer toxicity levels are determining factors when it comes to using hydrogels in live organisms. In this context, caseins have been considered as suitable polymer source because they are biodegradable, biocompatible and non-toxic (Tavares, Croguennec, Carvalho, \& Bouhallab, 2014).

Caseins are phosphorylated proteins, accounting for $80 \%(\mathrm{~m} / \mathrm{m})$ of total milk proteins. In milk, caseins are naturally present as casein micelles (CMs). 
CMs are supramolecular structures formed through the interaction of four main caseins fractions, $\alpha-s 1, \alpha-s 2, \beta, k-$ casein $\left(40,10,35,15 \%\right.$ w.w $\left.w^{-1}\right)$. They are joined through hydrophobic interactions, hydrogen bonds, electrostatic forces and calcium phosphate bonds to form spherical like structures (Broyard \& Gaucheron, 2015). The average CMs diameter ranges from 50 to $500 \mathrm{~nm}$ (Holt and Kruif, 2003) and presents higher polydispersity levels compared to other protein assemblies. CMs are highly hydrated and hold approximately $3.3 \mathrm{~g}$ water per $\mathrm{g}$ of protein (Huppertz et al., 2017).

Although CMs remain relatively stable in mild physicochemical conditions, the change in the $\mathrm{pH}$ toward casein's isoelectric point ( $\sim \mathrm{pH} 4.6)$ promotes the destabilization of the CMs and the formation of a casein hydrogel (Holt \& Kruif, 2003). The rheological properties of these hydrogels, such as the firmness, water holding capacity and porosity are dependent on the physicochemical state of the CMs (Silva et al., 2018). One possibility to improve the rheological properties of casein hydrogels is the crosslinking of CMs.

CMs crosslinking consists in the formation of covalent bonds within or between proteins (Ercili-Cura et al., 2012). Several crosslinking agents such as glutaraldehyde (Migneault et al., 2004; Xu, Teng, \& Wang, 2016), genipin (Casanova et al., 2017; Elzoghby, Helmy, Samy, \& Elgindy, 2013), and transglutaminase (Tgase) (Schorsch et al., 2000; Salcedo-Sandoval et al., 2015) have been studied previously. Tgase is a transferase produced by Streptoverticilium which acts by catalyzing the formation of covalent bonds between lysine and glutamine residues (Huppertz \& Kruif, 2008). The advantage it has over other crosslink agents is that it is a GRAS ingredient which increases its potential uses in food systems (Raak, Rohm, \& Jaros, 2017).

Recently, Casanova et al. (2017) showed that cyanidin-3-O-glucoside, an anthocyanin from Jaboticaba peel, binds spontaneously to sodium caseinate with a $\mathrm{pH}$-dependent mechanism. The authors demonstrated that hydrophobicdriven interactions were predominantly at $\mathrm{pH} 2$, whereas ionic strength-sensitive electrostatic interactions were the main binding forces dominant binding forces at $\mathrm{pH}$ 7. Given the above, the purpose of this study was to develop a hydrogel using acid gelation from cross-linked CMs that would be capable of storing and producing a controlled release of Jabuticaba extract (JE). The effects of both JE 
and Tgase in the CMs characteristics and in the hydrogel properties were

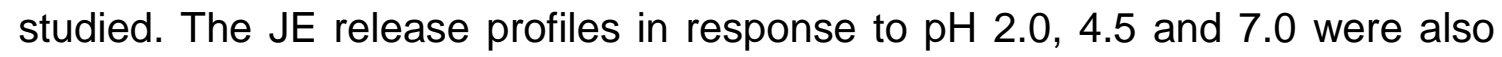
examined.

2. Materials and Methods

2.1. Materials

A CMs powder containing $85.70 \%$ total protein, $84.78 \%$ casein, $8.25 \%$ ash, $3.80 \%$ moisture and $0.83 \%$ lactose was obtained according to the methods described by Schuck et al. (1994). The milk was centrifuged in an industrial centrifuge to remove fat and dirt sediment. The skimmed milk was double tangentially microfiltrated. The first tangential filtration was performed with a $1.4 \mu \mathrm{m}$ membrane pore size to remove microorganisms and any remaining fat. The second microfiltration was performed with a membrane pore size $0.1 \mu \mathrm{m}$ to promote caseins and whey protein separation. After protein separation, the casein-rich retentate was diafiltrated (membrane pore size 0.1 $\mu \mathrm{m})$ five times using deionized water to remove lactose. The resulting dispersion was spray dried in a lab-scale single state spray dryer (Niro atomizer, GEA, Germany) with $180^{\circ} \mathrm{C}$ inlet air, $85^{\circ} \mathrm{C}$ outlet air temperatures and $18.3 \mathrm{Kg} / \mathrm{h}$ feed flow rate. The CMs powder samples were vacuum-sealed in aluminum foil-wrapped bags and stored at $4{ }^{\circ} \mathrm{C}$ until ready to use.

Jaboticaba extract (JE) was obtained according to the methods described by Rocha et al. (2017) with some minor modifications. Briefly, jaboticaba peel was manually removed from fresh fruits, washed with clean water and crushed using a food processor. It was placed in an extracting solution of $70 \%(\mathrm{v} / \mathrm{v})$ acidified ethanol $(\mathrm{pH} 2.0)$. The proportions for jaboticaba peel to ethanol was $1: 4 \mathrm{w} / \mathrm{w}$. The mixture was treated by ultrasounds for 10 min and kept at $4{ }^{\circ} \mathrm{C}$ overnight to allow polyphenol extraction. The resulting suspension was vacuum filtrated using a $0.45 \mu \mathrm{m}$ pore size filter. After filtration, the suspension was concentrated to $10 \%$ of its initial volume at $40{ }^{\circ} \mathrm{C}$ in a rotative evaporator (MA 120/2057, Marconi). The JE presented a pH level of 2.0, a total polyphenol content of $11.64 \mathrm{~g} / \mathrm{L}$ as determined by the FolinCiocalteau method (Larrauri, Rupérez, \& Saura-Calixto, 1997), and a monomeric anthocyanin content of $8.39 \mathrm{~g} / \mathrm{L}$ as determined by the $\mathrm{pH}$ differential 
method (Lee, Durst, \& Wrolstad, 2005). The JE sample was stored at $-18{ }^{\circ} \mathrm{C}$ until further use.

Microbial transglutaminase (Tgase) Activa ${ }^{\circledR}$ YG (Tgase, EC. 2.3.2.13) was provided by Ajinomoto Foods SAS (Mesnil- Saint-Nicaise, France). According to Ajinomoto, the product presents activity levels of 100 units $/ g$ of powder. Glucono-ס- lactone (GDL) was purchased from Sigma-Aldrich (São Paulo, Brazil). All other chemical reagents used were analytical grade.

\subsection{Sample preparation}

The CMs powder was rehydrated in ultrapure water with $2 \mathrm{mM}$ of sodium chloride to reach a casein concentration of $4.5 \%(\mathrm{w} / \mathrm{w})$. The CMs suspension was kept under magnetic stirring at $900 \mathrm{rpm}$ at room temperature until the CMs were completely rehydrated. Hydration time took approximately 72 hours. Rehydration was confirmed by verifying particle size with a Zetasizer Nano-S (Malvern Instrument, Worcestershire, UK). The suspension was considered to be completely rehydrated when only one population of particles smaller than $400 \mathrm{~nm}$ was detected (data not shown). Sodium azide in a concentration of $0.03 \%(\mathrm{w} / \mathrm{w})$ was added to prevent microbial growth.

The CMs suspension $\mathrm{pH}$ was adjusted to 6.7 using $1 \mathrm{M} \mathrm{HCl}$ or $1 \mathrm{M}$ $\mathrm{NaOH}$. It was then divided in four samples, as can be seen in Table 1. Tgase was rehydrated in ultrapure water at a concentration of $10 \%(\mathrm{w} / \mathrm{w})$. It was then added to the CMs samples to a concentration of $3 \mathrm{U}$ per $\mathrm{g}$ of CMs. Crosslink reactions occurred at $45{ }^{\circ} \mathrm{C}$ after 1 hour and were halted by incubating the samples at $85^{\circ} \mathrm{C}$ for $5 \mathrm{~min}$. The samples were then put in a $0^{\circ} \mathrm{C}$ ice bath to lower their temperatures to $4{ }^{\circ} \mathrm{C}$. The samples were allowed to return to room temperature, i.e. $25{ }^{\circ} \mathrm{C}$. The $\mathrm{CMs}$ samples were stirred continuously in a magnetic stirrer while JE was added with a dropper to a concentration of $2 \%$ $(\mathrm{w} / \mathrm{w})$. The samples were stirred at $1000 \mathrm{rpm}$ in a magnetic stirrer for $10 \mathrm{~min}$ at $25^{\circ} \mathrm{C}$ to allow the JE compounds and CMs to interact.

Acid hydrogels were produced by chemical acidification of the samples. GDL at concentration of $2 \%(\mathrm{w} / \mathrm{w})$ was added to all suspension samples and stirred until complete GDL solubilization was reached. The gelation process occurred at $30{ }^{\circ} \mathrm{C}$ when the samples' $\mathrm{pH}$ reached 4.5. The $\mathrm{pH}$ drop was 
monitored as a function of time using a pH-meter Hanna Instrument HI2223 (São Paulo, Brazil). Data were recorded using Real-Time Logging HI 9200e5.0.26 Hanna Instrument (São Paulo, Brazil). Acidification monitoring began right after complete GDL dissolution. The treatment designation is presented in Table 1.

\subsection{Suspension characterization}

The suspensions were evaluated for their polymerization degrees prior to gelation using SDS-PAGE electrophoresis, hydrodynamic diameter (Dh)

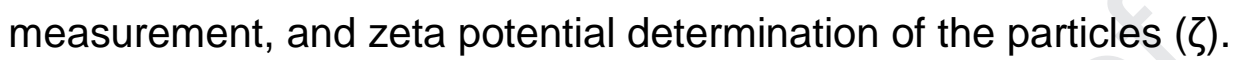

\subsubsection{SDS-PAGE Electrophoresis}

SDS-PAGE electrophoresis in the polyacrylamide gel was determined according to the method described by Judd (1994) in 3 phase gel. The electrophoresis tests were run in an electrophoresis vertical cube (Mini-Protean Tetra System, Bio-Rad California, U.S.A) using a Tris-glycerin buffer solution $(\mathrm{pH}$ 8.6). The CMs samples were prepared in a concentration of $4.5 \% \mathrm{w} / \mathrm{w}$. An aliquot of each suspension was allowed to react with a 2-mercaptoetanol buffer solution (1:4). The molecular weight marker (Precision Plus Protein ${ }^{\mathrm{TM}}$, BIORAD, São Paulo, Brazil), casein standard and $8 \mu \mathrm{L}$ of each suspension were placed on top of the polyacrylamide gel. It was applied at $100 \mathrm{~V}$ for 10 minutes, $80 \mathrm{~V}$ for 15 minutes and $60 \mathrm{~V}$ for 300 minutes using a power source (PowerPacTM Basic, Bio-Rad California, U.S.A). The gels were dyed using Coomassie ${ }^{\circledR}$ Brilliant Blue R-250 dissolved at $0.3 \%$ in a methanol: acetic acid: water solution $(4.5: 1: 4.5 \mathrm{v} / \mathrm{v})$ at $25^{\circ} \mathrm{C}$ for 4 hours. After the dyeing phase, the gels were immersed in methanol to obtain a clear contrast between the bands and the background.

\subsubsection{Dynamic Light Scattering (DLS)}

The particles' hydrodynamic diameters were determined with a Zetasizer Nano-S (Malvern Instrument, Worcestershire, UK). The analysis was carried out at $173^{\circ}$ scattering using a $632.8 \mathrm{~nm}$ wavelength excitation angle. Samples were diluted to $1: 20$ in the same solution used for CMs rehydration and allowed to rest at $25{ }^{\circ} \mathrm{C}$ for $5 \mathrm{~min}$. The $\mathrm{pH}$ level of all the samples was adjusted to 6.7. 
219 Suspension viscosity $(\eta)$ was $1.033 \mathrm{mPa}^{-1} \mathrm{~s}^{-1}$; each cell reading was performed in

220 triplicate.

221

222

223

224

$$
D h=\frac{K b T}{3 \pi \eta D t}
$$

225

226

227

228

229

232

233

234

235

236

237

238

239

240

241

242

243

Particle Dh was determined using the Stokes-Einstein equation with a diffusion coefficient (Dt) extracted from the correlation curve using the cumulant method, as follows:

Where $\mathrm{Kb}$ is Boltzmann's constant and $\mathrm{T}$ is temperature.

2.3.3. $\zeta$-potential measurements

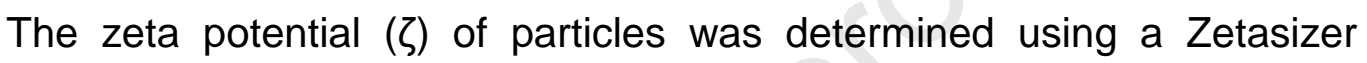
Nano-S (Malvern Instrument, Worcestershire, UK) under the same conditions described for the DLS measurements above. Capillary cells were used to perform the analysis. The measurements were carried out using 50 volts, and the calculations were made according to the Henry equation, Equation 2.

$$
\zeta=\frac{3 \eta \mu}{2 \varepsilon f(k R h)}
$$

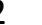

where $\eta$ is the solvent viscosity $\left(\mathrm{Pa} \mathrm{s}^{-1}\right)\left(1.033 \mathrm{mPa} \mathrm{s}{ }^{-1}\right), \mu$ is the electrophoretic mobility $\left(\mathrm{V} \mathrm{Pa}^{-1} \mathrm{~s}^{-1}\right), \varepsilon$ is the medium dielectric constant (dimensionless) and $\mathrm{f}(\mathrm{kRh})$ is Henry's function. Because the particle analysis was conducted in aqueous media, the Smoluchowski approximation value of 1.5 was adopted for $\mathrm{f}(\mathrm{kRh})$.

\subsection{Hydrogel characterization}

The hydrogel samples were evaluated for oscillatory dynamic rheology and water holding capacity (WHC). Their microstructures were determined using confocal laser scanner microscopy and the pore sizes were determined by $2 \mathrm{D}$ - correlation analysis of the CLSM images. The JE sample release profiles were measured under different $\mathrm{pH}$ conditions. 


\subsubsection{Dynamic rheological measurements}

Shear stress and frequency sweep tests were performed in the casein hydrogel samples. CMs samples were prepared at concentration of $4.5 \% \mathrm{w} / \mathrm{w}$ using ultrapure water with $2 \mathrm{mM}$ of calcium chloride. The GDL was incorporated into the CMs samples at a $2 \% \mathrm{w} / \mathrm{w}$ concentration to promote samples acidification. After the GDL was added, the CMs samples were stirred for 30 seconds. The hydrogel samples were allowed to gel at $30{ }^{\circ} \mathrm{C}$ in a $50 \mathrm{~mL}$ cylindrical glass. Once their $\mathrm{pH}$ reached 4.5, the hydrogel samples were carefully placed in a modular advanced rheometer system (Haake Mars, Thermo Electron Corp., Karlsruhe, Germany), equipped with a thermostatic bath (Phoenix 2C30P, Thermo Electron Corp., Karlsruhe, Germany). First, the hydrogels samples' linear viscoelastic regions were evaluated through shear stress sweep test. The shear stress had increased from 0.01 to $10000 \mathrm{~Pa}$ at a constant frequency $(1 \mathrm{~Hz})$. The hydrogel samples linear viscoelastic regions were determined when their loss tangent assumed constant values. Second, a frequency sweep test was carried out applying a variable frequency from 0.1 to $10.0 \mathrm{~Hz}$ in the hydrogel samples. Both experiments were carried out at $37^{\circ} \mathrm{C}$. This temperature was chosen because it is close to the human body temperature and thus represents a potential environmental application for the hydrogels studied. In both assays, a stainless-steel cone-and-plate geometry (Cone $\mathrm{C} 35 / 2^{\circ} \mathrm{Ti}$ ) with a gap of $1 \mathrm{~mm}$ was used.

The water holding capacity (WHC) was determined according to the method described by Silva et al. (2018). Each hydrogel sample was allowed to form in $50 \mathrm{~mL}$ centrifuge tubes at $30^{\circ} \mathrm{C}$ until their $\mathrm{pH}$ reached 4.5. The hydrogels were centrifuged at $3000 \mathrm{~g}$ (Heraus megafuge 8R centrifuge, Thermo scientific) at $37^{\circ} \mathrm{C}$ for $15 \mathrm{~min}$. The supernatant was carefully separated and weighed. The WHC of the hydrogel samples was calculated using equation 3.

$$
W C H \%=\frac{(m i-m s)}{m i} X 100
$$

Where $m i$ is the initial mass and $m s$ is the supernatant mass. 
277 to the method described by Andoyo, Guyomarc'h, Cauty, \& Famelart (2014).

278 Suspension samples were labeled using $0.2 \mathrm{~g} / \mathrm{kg}$ of rhodamine B isothiocyanate (RITC) (Sigma Sigma-Aldrich, Sao Paulo, Brazil). The suspensions were stirred for $5 \mathrm{~min}$ at room temperature to ensure RITC solubilization. Hydrogel formations occurred in petri dishes (MatTek Corporation, Ashland, USA) at 30 ${ }^{\circ} \mathrm{C}$ when $2 \%(\mathrm{w} / \mathrm{w}) \mathrm{GDL}$ was added. After the hydrogels formed, the samples were studied using a Helion-Neon laser (excitation at $543 \mathrm{~nm}$ and emission at $625 \mathrm{~nm}$ ) in a Zeiss LSM 510 Meta Confocal microscope.

\subsubsection{Pore size determination}

Pore size was determined by 2-D correlation analysis as described by Silva et al. (2018). Briefly, CLSM images (CLSM) were digitalized on a grey scale as $512 \times 512$ pixel matrix. Each pixel was given a greyscale range from 0 (black) to 216 (white). Proteins appear in the images as clear spots while pores appear as the darker regions. When a physical value depends on an extension, the value can be analyzed using a correlation function. The spatial coordinate function used to analyses the images is written as equation 4.

$$
C(\vec{\delta}) \equiv \frac{I(\vec{r}) I(\vec{r}+\vec{\delta})}{I^{2}}-1
$$

293

2.5. Controlled release

Ten grams of the hydrogel samples containing JE were allowed to form in closed shot flasks under the same conditions described in section 2.2. The hydrogel samples' release of anthocyanins was determined by immersing the hydrogels in three buffer solutions at different $\mathrm{pH}$ levels. To mimic a human stomach $\mathrm{pH}$, a buffer solution of $0.1 \mathrm{M} \mathrm{KCl}: \mathrm{HCl}$ was adjusted to $\mathrm{pH} 2$. To mimic a $\mathrm{pH}$ value close to the small intestine, a buffer solution of $0.1 \mathrm{MHEPES}$ at $\mathrm{pH}$ 7.0 was used. The release experiments were also performed at $\mathrm{pH} 4.5$, which is the hydrogels $\mathrm{pH}$, using a buffer solution of $0.1 \mathrm{M}$ acetic acid: sodium acetate. The hydrogel samples were placed in closed shot flasks and covered with 20 $\mathrm{mL}$ of each buffer solution (Figure 7.1). The systems were incubated in a water bath at $37{ }^{\circ} \mathrm{C}$ without light. An aliquot of $60 \mu \mathrm{L}$ of the supernatants was 
305

withdrawn from each sample to determine total monomeric anthocyanin release.

2.6. Monomeric anthocyanin measurements

Monomeric anthocyanin measurements were carried out according to Lee, Durst, \& Wrolstad (2005) with adaptations made for a microplate reader as proposed by Lee, Rennaker, \& Wrolstad (2008). The total monomeric anthocyanin levels were calculated using Equation 5. The 100\% level was determined by placing the same quantity of fruit extract used in the hydrogel sample formulation into $20 \mathrm{~mL}$ of each buffer solution. All experiments were performed in triplicate. The results are expressed in percentages of the released anthocyanins.

$$
A n t=\frac{A M W D F 1000}{\varepsilon 1}
$$

Where Ant is the anthocyanin content in terms of cyanidin-3-glucoside equivalent expressed in $\mathrm{mg} / \mathrm{L}, \mathrm{A}$ is (Absorbance at $520 \mathrm{~nm}$ - Absorbance at 700 $\mathrm{nm}$ ) at $\mathrm{pH} 1$ subtracting the (Absorbance at $520 \mathrm{~nm}$ - Absorbance at $700 \mathrm{~nm}$ ) at $\mathrm{pH} 7, \mathrm{MW}$ is the molecular weight of cyanidin-3-glicoside $(449.2 \mathrm{~g} / \mathrm{mol})$, DF is the dilution factor used (5), $\varepsilon$ is the molar extinction coefficient for cyanidin-3glucoside $\left(26,900 \mathrm{~L} \mathrm{~mol}^{-1} \mathrm{~cm}^{-1}\right), 1000$ is the conversion factor from $\mathrm{g}$ to $\mathrm{mg}$, and 1 is the path length in $\mathrm{cm}$.

\subsection{Statistical analysis}

The data were processed using variance analysis (ANOVA) with SAS university edition software to access the influence of Tgase and JCE in the hydrogel's features. The Tukey HSD test was applied to compare the mean values. $p<0.05$ was used to determine significance. All experiments were performed in triplicate.

\section{Results and discussion}

\subsection{Suspension characterization}

Figure 1 shows SDS-PAGE electrophoresis analysis results. The CC sample represents the control CMs sample without the reticulation process, which had also been submitted to the heat treatments for Tgase crosslinking and inactivation as well the subsequent ice bath cooling phase. Even though 
335 the CMs powder treatment process was designed to eliminate all serum

336 proteins, it is possible to observe low molecular weight molecules in the 337 samples, as can be seen in the band formed between 10 and $15 \mathrm{KDa}$. When 338 sample $\mathrm{CC}$ is compared to sample $\mathrm{A}$, no polymerization degree modification 339 caused by heating can be observed. Samples $A$ and $C$ presented similar bands, 340 as well as samples B and D. The presence of Tgase induced certain differences 341 between bands. The samples treated with Tgase showed polypeptide presence 342 and had higher molecular weights than the non-treated samples. All the casein monomer bands in samples $B$ and $D$ were less dark than samples $A$ and $C$. At the same time, a darker path was observed between $75 \mathrm{KDa}$ and $37 \mathrm{KDa}$ in samples $B$ and $D$ due to the formation of casein oligomers. Similar results were found by Chen, Li, Han, Yuan, \& Zhang (2018) when they studied the crosslink effects when Tgase was added to a milk protein concentrate (MPC). They observed a gradual decrease in the protein bands when a longer reaction time was allowed. It is worth noting that the presence of JE did not change the caseins' polymerization degrees, as observed in previous studies ( $\mathrm{He}, \mathrm{Xu}$, Zeng, Qin, \& Chen, 2015), interactions between anthocyanins and caseins did not change the proteins' primary structure. Thus, the same band patterns were observed in the both the samples with and without JE.

CMs size distribution in the sample suspensions are shown in Figure 2 and Table 2. The main differences were observed between native (samples $A$ and C) and crosslinked CMs (samples B and D). Crosslinked CMs (samples B and D) had hydrodynamic diameter of around $160 \mathrm{~nm}$, whereas samples without Tgase (A and $C$ ) had diameters of approximately $175 \mathrm{~nm}$. Similar results were founded by Nogueira et al. (2018) when studying CMs suspensions at $\mathrm{pH}$ levels close to milk $\mathrm{pH}$. Tgase promotes a covalent bond formation between glutamine and lysine residues (Huppertz \& Kruif 2008). Tgase favors crosslinks between $\mathrm{k}$ and $\beta$ - casein fractions in CMs over crosslinks with $\alpha$ caseins (Smiddy, Martin, Kelly, Kruif, \& Huppertz, 2006). This difference in crosslink levels is due to casein fraction position in the micelle structure. Because a-s caseins are located within the CMs, lower Tgase activity was observed compared to Tgase activity for $\beta$ and $\mathrm{k}$ - casein fractions (Smiddy et al., 2006). Alternately, the $\mathrm{k}$ - casein's location on the CMs surface makes it 
more accessible to crosslinked reactions. Therefore, an increase in the polymerization degree of the k-casein reduced the CMs size (Duerasch, Wissel, \& Henle, 2018).

JE presence did not interfere with CMs size distributions. In previous studies, favorable interactions between casein and anthocyanins, i.e. Gibbs energy assuming negative values, have been reported. He et al. (2015) used $\beta$ and $\alpha$-s caseins to encapsulate anthocyanins from grape skins, and it has been suggested that the hydrophobic interactions between malvidin-3-O-glucoside with $\beta$ - casein and the van-der-walls and hydrogen bonds formed between $\alpha$ casein and the anthocyanin are usually predominant. Casanova et al. (2017) showed that cyanidin-3-O-glucoside interacted internally with sodium caseinate through electrostatic forces at $\mathrm{pH}$ 7. Therefore, it is likely the interaction between the JE anthocyanins occurred internally without causing any modification in the CMs surface charge.

The $\zeta$ - potential did not change in any of the samples (Table 2). The unaltered Tgase CMs crosslinks are in accordance with Silva et al. (2018) and Kruif \& Hold (2003). Tgase was able to catalyze a covalent bond formation between lysine and glutamine resides by acyl transition reactions (Jaros, Partschefeld, \& Henle, 2006). This bond formation occurred in the CMs themselves. Thus, it did not cause any polymerization between adjacent CMs. The majority of JE anthocyanins were cyanidin-3-O-glucoside and delphinidin-3glucoside (De Castro et al., 2014) and their charges varied according to the $\mathrm{pH}$ of the medium used. In acidic $\mathrm{pH}$ mediums, the anthocyanins were positively charged (Dangles \& Fenger, 2018). The presence of positively charged anthocyanins in JE did not influence the CMs charges. Casanova et al. (2017), $\mathrm{He}$ et al. (2015) and Wei et al. (2018) found favorable interactions between anthocyanins and caseins, i.e. Gibbs free energy lower than zero. The $\zeta$ potential and size results found in this study in combination with the results detailed in previous literature suggest an internal complexation of JE within the CMs.

\subsection{Hydrogel characterization}

\subsubsection{Acidification monitoring}


The $\mathrm{CMs} \mathrm{pH}$ variations observed after the GDL addition are shown in

401 Figure 3. All curves represent behavior characterized by a rapid decrease in $\mathrm{pH}$ after the first 20 min of the acidification process, followed by a slower $\mathrm{pH}$ decrease rate in the following minutes. The presence of Tgase did not affect the acidification profiles of the samples, as has been shown by Raak, Rohm, \& Jaros (2017 • ). Indeed, the curves for samples C and D are located below the curves for samples $A$ and $B$, but their tendencies were similar. JE has a low $\mathrm{pH}$ $(\mathrm{pH} 2)$, therefore incorporating JE in the CMs samples caused a $\mathrm{pH}$ drop at the beginning of the acidification process. The hydrogel samples with JE thus reached a $\mathrm{pH} 4.5$ forty minutes before the hydrogels without JE. The initial $\mathrm{pH}$ levels recorded for samples without JE were 6.49 (without Tgase) and 6.43 (with Tgase), while the first recorded $\mathrm{pH}$ levels in samples with JE were 5.99 (without Tgase) and 5.89 (with Tgase). For this reason, a shift in the acidification curves in the dispersions containing JE can be observed, as can be seen in Figure 3.

\subsubsection{Dynamic oscillatory rheological measurements}

The rheological behavior of acid milk gels, which are similar to the casein hydrogels proposed in this study, depends on the quantity and strength of the interactions that occur between caseins (Lucey, 2017). Shear stress and frequency sweep results are shown in Figures 4.1 and 4.2; both results are expressed as loss tangents. Loss tangent is defined as the ratio between viscous and elastic moduli. Lower loss tangent values indicate hydrogels with a prominently elastic modulus compared to those with a viscous modulus. A shear stress sweep experiment (Figure 4.1) was conducted to determine the linear viscoelastic region of the hydrogel samples and the critical shear stress values the hydrogels can withstand without permanent structure loss. The end of the linear viscoelastic region occurred when applied stress was important enough to break the bonds within the protein matrix (Everett \& Olson, 2000). The hydrogel samples all behaved similarly where the linear viscosity region ends. This behavior was characterized by an abrupt change in loss tangent curves. It can be explained by types of interactions found on hydrogel structures. Caseins associate mainly by hydrophobic interaction, and there is no mechanism to relieve the stress that occurs. For this reason, a hydrogel can 
withstand certain stress levels, but when the interactions among caseins start to break and crack the surface, propagation occurs rapidly (Ma et al., 2016). Hydrogel samples treated with Tgase which contained JE showed shorter linear viscoelastic regions compared to the other hydrogel samples. This indicates lower structure stability (Tunick, 2010). This phenomenon occurred only in the hydrogel sample with Tgase. Anthocyanin interactions with caseins promote changes in the caseins' secondary structure (He et al., 2015), which may impact the protein-protein interactions. However, the structure of the hydrogel samples without Tgase were more flexible which facilitated casein rearrangements and allow the samples to withstand greater stress levels until the interactions break. The opposite was the case for hydrogels with Tgase. Tgase promoted the formation of covalent bonds within the hydrogel matrix. The greater number interactions in the protein matrix made the matrix more inflexible (Rohm, Ullrich, Schmidt, Löbner, \& Jaros, 2014). Therefore, the modified protein-protein interactions resulted in fewer protein rearrangements and brought about a shorter linear viscoelastic region.

In general, all samples showed a correlation between loss tangent and frequency, Figure 4.2. The hydrogel sample with Tgase but no JE showed lower loss tangent values compared to other samples, while the hydrogel without Tgase or JE showed the highest loss tangent values in the frequency sweep, Figure 4.2. The samples can be classified by two factors: enzymatic crosslinking and JE loading. The Tgase treatment diminished loss tangent values of the samples as compared to the untreated hydrogel samples, as can be observed by comparing samples A - B, and C - D. The hydrogel samples with JE presented higher loss tangent values, as can be observed by comparing samples A - C and B - D. Tgase increased the hydrogel samples' elasticity, while the presence of JE decreased their elasticity. There are two explanations for this behavior. First, variations in acidification rates caused by the addition of JE also influenced the frequency sweep of the hydrogel samples with JE. Jacob, Nobel, Jaros, \& Rohm (2011) studied the effects of acidification rates in acid milk gels using a rheological approach and used a system similar to the one in this study. They found a significant decrease in gel stiffness due to higher rates of acidification for both crosslinked and non-crosslinked milk. As shown in Figure 3, samples containing JE began acidification at lower $\mathrm{pH}$ levels 
than the other samples because of the $\mathrm{pH}$ decrease caused by the addition of

468 JE. The JE extract had to be held at lower $\mathrm{pH}$ values $(\mathrm{pH} 2.0)$ in order to keep 469 the anthocyanins stable. Therefore, samples with JE (C and $D)$ reached a $\mathrm{pH}$ 4.5 level forty minutes before the samples without JE ( $A$ and $B$ ).

Nevertheless, the effects of the polyphenols present in the JE should not be overlooked. In this study, the interactions between the JE and the caseins did not cause significant changes in the $\zeta$-potential or the CMs hydrodynamic diameter. CMs were stabilized internally by hydrophobic interactions and colloidal calcium phosphate (Lucey \& Horne, 2018). Thus, these two forces counterbalanced the JE's tendency to alter casein-casein interactions. However, the colloidal system state change from suspension to gel was followed by CCP solubilization (Lee \& Lucey, 2004). Thus, the destabilized forces caused when the JE was added were no longer balanced out by the CCP, which ultimately produced hydrogels with higher loss tangent values. Silva et al., 2017 have studied the impact on the rheological properties of yogurt when grape extract was added. The authors showed that an addition of $3 \%$ of grape extract containing $962 \mathrm{mg} \mathrm{GAE} / \mathrm{g}$ of phenolic compounds increased acidification time, but significantly decreased gel strength. Similar results have been found by Pereira et al. (2016). The authors found that adding a JE with a concentration of $0.5 \%$ to Petit Suisse cheese decreased its G' and increased its loss tangent. This suggests an interference in protein network formation when JE was present. Recent studies have demonstrated that the changes in the secondary structure conformation of $\alpha$ - and $\beta$ - caseins are caused by an interaction with anthocyanins (Lang et al., 2019; Wei et al., 2018; He et al., 2016). Lang et al. (2019) observed 2.86 times more $\alpha$ - helix and 1.17 times more $\beta$-sheet in $\beta$ - casein suspensions when malvidin-3-O-glucoside was present. These changes in secondary structure may cause a decrease in milk gel strength when polyphenol extracts are present.

\subsubsection{Water Holding Capacity (WHC)}

In these experiments, the hydrogel samples ability to hold water was measured under centrifugal force. Higher values were observed for samples treated with Tgase. The crosslinked hydrogels showed 21.34 and $22.33 \%$ WHC when JE was absent or present, respectively. However, without the enzymatic 
500 treatment, the $\mathrm{WCH}$ dropped to 12.36 and $12.33 \%$ when JE was absent or

501 present, respectively. Sun et al. (2018) found an 82.78\% WHC using a CMs 502 powder that had a similar protein profile. The differences can be attributed to 503 the methodology used as they applied a centrifugal force of $1200 \mathrm{~g}$ for $15 \mathrm{~min}$, 504 which is $60 \%$ less intense then the centrifugal force applied in the current study. 505 The WHC ratio of non-crosslinked to crosslinked casein hydrogels are in 506 accordance with the results published by Silva et al. (2018). Tgase treatment 507 promotes a denser and more homogeneous network formation in the casein 508 hydrogel samples (Figure 5) because it catalyzes the formation of covalent 509 bonds within the protein matrix. The Tgase action resulted in greater interaction 510 between the proteins. The higher crosslink point extensions conferred a protein 511 network with a smaller pore size for the hydrogel samples, as shown in Figure 512 6.2. The water diffusion was made more difficult when the hydrogel matrix was 513 more compact (Ercili-Cura, et al., 2012). The presence of JE did not affect the 514 WHC of the hydrogel samples.

\subsubsection{Hydrogel microstructure}

The images taken of hydrogel sample microstructures both in the presence of JE and Tgase were obtained by CLSM and are presented in Figure 5. It can be observed that the network density of samples $B$ and $D$ is more homogeneous and compact than that of samples $A$ and $C$. The CLSM images were submitted to 2D-correlation analysis in order to numerically estimate the pore size of each sample (Figure 6.1 and 6.2). The hydrogel samples without an enzymatic treatment showed a mean pore size of $1.40 \pm 0.14 \mu \mathrm{m}$ for sample $A$, and $1.72 \pm 0.12 \mu \mathrm{m}$ for sample $\mathrm{C}$. In the samples treated with Tgase, pore size ranged from $0.63 \pm 0.02$ for sample $B$, and $0.68 \pm 0.01$ for sample $D$. According to previous literature (Silva et al., 2018; Ercila-Cura et al., 2012), Tgase causes a porosity reduction in acid milk gels. Thus, similar behavior in the CMs hydrogel samples was to be expected. Jacob, Jaros, \& Rohm (2011) have argued that the presence of Tgase promotes the formation of casein oligomers. These act as a skeleton for gel development as acidification occurs. Hence, if the acidification rates occur over a sufficiently long time period to allow the caseins to regroup into a 3D structure, the formed gel will be denser and more homogeneous. 
The addition of JE significantly increased $(p<0.05)$ the pore size of the casein hydrogel samples without Tgase (Figure 6.2). The fast acidification rate

535 promoted a coarser protein matrix structure. However, no significant difference $536(p>0.05)$ in pore size was observed in the hydrogel samples treated with 537 Tgase. Therefore, Tgase plays an essential role in maintaining hydrogel 538 structure when JE is entrapped.

\section{3.2.5. Controlled release}

The release profiles of the hydrogel samples both with or without Tgase at three $\mathrm{pH}$ values $(2.0,4.5$ and 7.0) is presented in Figure 7.2. The Tgasetreated hydrogel samples presented slower release rates than the non-treated hydrogel samples at all pH levels evaluated. Song, Zhang, Shi, \& Li (2010) found similar results. In their study, Tgase was applied to hydrogel samples in two different concentrations and the hydrogel sample with the greater amount of Tgase showed a slower delivery rate of Vitamin B12 at a pH level of 7.4. Using GP as crosslink agent, Song, Zhang, Yang, \& Yan (2009) also found a slower release rate when the amount of GP in the system was increased. As can be observed in the CLSM images, the hydrogel samples treated with Tgase presented a compact structure, with smaller pore size. This ultimately decreased anthocyanin diffusion and lowered their release rate.

Release rate increases were observed at higher $\mathrm{pH}$ levels in the mediums used. Two factors should be taken into consideration: (i) protein matrix behavior in the given $\mathrm{pH}$ conditions, and (ii) the strength of the interactions between the anthocyanins and the protein matrix at $\mathrm{pH} 2.0,4.5$ and 7.0 levels. The buffer solution was placed over the casein hydrogel samples. For this reason, the only part of the hydrogel samples that came into contact with the buffers was their surface. This means that the contact area for anthocyanin diffusion was the transversal area of the flask containing the hydrogel sample. The first layer of the hydrogel samples come into contact with the specific buffer $\mathrm{pH}$ value which was different from the hydrogel samples' $\mathrm{pH}$. Thus, changes in the protein charges were expected. JE release at $\mathrm{pH} 7.0$ and 4.5 levels were similar. At pH 7.0, a lower concentration of hydrogen ions in the buffer solution was observed. Thus, the protein chains acquired a negative charge. This negative charge induced an increase in repulsive forces among 
566 the protein chains, which weakened the hydrogel matrix (Lucey, 2009) and

567 ultimately freed the JE from the hydrogel samples. At $\mathrm{pH} 4.5$, the caseins were 568 close to their isoelectric point, therefore the overall charges were close to zero.

569 The possibility for similar release rates came not from protein matrix relaxation, 570 but from a decrease in the strength of interactions between the JE and casein at 571 this particular $\mathrm{pH}$ level. However, more studies are required to confirm this 572 hypothesis. At $\mathrm{pH}$ 2.0, a charge modification in the surface of the hydrogel 573 samples was also to be expected, but contrary to the conditions at $\mathrm{pH} 7.0$, the 574 protein chains were protonated and assumed positive charges because the $\mathrm{pH}$ 575 was below their isoelectric point of $4.6 \mathrm{pH}$ (Horne, 2009). However, at pH 2.0 576 the anthocyanin release rate was minimal. This behavior can be explained by 577 the interactions that can occur between the proteins and anthocyanins. 578 Casanova et al. (2017) found that binding forces between cyanindin-3-O579 glucoside and sodium caseinate were higher at $\mathrm{pH} 2.0$ than at $\mathrm{pH} 7.0$ at $36{ }^{\circ} \mathrm{C}$. 580 The forces changed in degree and nature when the $\mathrm{pH}$ of the medium was 581 modified. At an acid $\mathrm{pH}$, the complexes formed between sodium caseinate and 582 cyanindin-3-O-glucoside were dominated by hydrophobic forces, whereas van 583 der Waals bonds and electrostatic interactions determined the nature of the 584 complexation between anthocyanins and proteins at $\mathrm{pH}$ 7.0. Cyanindin-3-O585 glucoside was the primary anthocyanin present in the JE and it interacted more 586 strongly with proteins at acid pH levels. Thus, this strong interaction contributed 587 to a slower release rate at $\mathrm{pH}$ 2.0. Due the complexity of the systems in this 588 study, the thermodynamic parameters were not determined, however our 589 knowledge of them from previous studies has been essential to understanding 590 the release properties demonstrated by the JE.

\section{4. Conclusion}

This study has shown that crosslinked casein hydrogels can be used to carry and provide controlled delivery of JE. The rate of release can be modulated by the presence of Tgase. JE did not alter the CMs structure in suspension. In general, the crosslinked systems showed slower JE release rates at all $\mathrm{pH}$ levels evaluated, with a maximum release at $\mathrm{pH} 7.0$ and a minimum at $\mathrm{pH}$ 2.0. This behavior gave the hydrogel samples the ability to retain or release JE, depending upon the $\mathrm{pH}$ of the medium studied. Additional 
599

600

601

602

603

604

605

606

607

608

609

610

611

612

613

614

615

616

617

618

619

620

621

622

studies under simulated and/or in vivo digestion conditions must be carried out to determine CMs hydrogels' ability to protect JE and potentially increases its bioavailability.

\section{Acknowledgements}

We gratefully acknowledge the Brazilian funding agencies CNPq, Fapemig and the Coordenação de Aperfeiçoamento de Pessoal de Nível Superior - Brasil (CAPES) - Finance Code 001, for the financial support.

\section{References}

Ahmed, E. M. (2015). Hydrogel: Preparation, characterization, and applications: A review. Journal of Advanced Research, 6(2), 105-121. https://doi.org/10.1016/j.jare.2013.07.006

Andoyo, R., Guyomarc'h, F., Cauty, C., \& Famelart, M. H. (2014). Model mixtures evidence the respective roles of whey protein particles and casein micelles during acid gelation. Food Hydrocolloids, 37, 203-212.

Bera, S., \& Dutta, D. (2017). Encapsulation and release of a bacterial carotenoid from hydrogel matrix: Characterization, kinetics and antioxidant study. Engineering in Life Sciences, 17(7), 739-748. https://doi.org/10.1002/elsc.201600238

Broyard, C., \& Gaucheron, F. (2015). Modifications of structures and functions of caseins: a scientific and technological challenge. Dairy science \& technology, 95(6), 831-862.

Caló, E., \& Khutoryanskiy, V. V. (2015). Biomedical applications of hydrogels: A review of patents and commercial products. European Polymer Journal, 65, 252-267.

Casanova, F., Chapeau, A. L., Hamon, P., de Carvalho, A. F., Croguennec, T., \& Bouhallab, S. (2017). $\mathrm{PH}$ - and ionic strength-dependent interaction between cyanidin-3-O-glucoside and sodium caseinate. Food Chemistry. https://doi.org/10.1016/j.foodchem.2017.06.081 
Casanova, F., Nogueira Silva, N. F., Gaucheron, F., Nogueira, M. H., Teixeira, A. V. N. C., Perrone, I. T., Alves, M. P., Fidelis, P.C., \& Carvalho, A. F. (2017). Stability of casein micelles cross-linked with genipin: A physicochemical study as a function of $\mathrm{pH}$. International Dairy Journal, 68, 70-74. https://doi.org/10.1016/j.idairyj.2016.12.006

Chen, L., Li, Y., Han, J., Yuan, D., Lu, Z., \& Zhang, L. (2018). Influence of transglutaminase-induced modification of milk protein concentrate (MPC) on yoghurt texture. International Dairy Journal, 78, 65-72. https://doi.org/10.1016/j.idairyj.2017.10.001

Dangles, O., \& Fenger, J. A. (2018). The chemical reactivity of anthocyanins and its consequences in food science and nutrition. Molecules, 23(8), 1970.

De Castro, V. C., Da Silva, P. H. A., De Oliveira, E. B., Desobry, S., \& Humeau, C. (2014). Extraction, identification and enzymatic synthesis of acylated derivatives of anthocyanins from jaboticaba (Myrciaria cauliflora) fruits. International Journal of Food Science and Technology, 49(1), 196-204. https://doi.org/10.1111/ijfs.12298

Duerasch, A., Wissel, J., \& Henle, T. (2018). Reassembling of Alkali-Treated Casein Micelles by Microbial Transglutaminase. Journal of agricultural and food chemistry, 66(44), 11748-11756.

Elzoghby, A. O., Helmy, M. W., Samy, W. M., \& Elgindy, N. A. (2013). Spraydried casein-based micelles as a vehicle for solubilization and controlled delivery of flutamide: Formulation, characterization, and in vivo pharmacokinetics. European Journal of Pharmaceutics and Biopharmaceutics, 84(3), 487-496. https://doi.org/10.1016/j.ejpb.2013.01.005

Ercili-Cura, D., Lille, M., Legland, D., Gaucel, S., Poutanen, K., Partanen, R., \& Lantto, R. (2012). Structural mechanisms leading to improved water retention in acid milk gels by use of transglutaminase. Food Hydrocolloids, 30(1), 419-427. https://doi.org/10.1016/j.foodhyd.2012.07.008 
656 Everett, D. W., \& Olson, N. F. (2000). Dynamic Rheology of Renneted Milk Gels

657

658

659

660

661

662

663

664

665

666

667

668

669

670

671

672

673

674

675

676

677

678

679

680

681

682 Containing Fat Globules Stabilized with Different Surfactants. Journal of Dairy Science, 83(6), 1203-1209. https://doi.org/10.3168/jds.S00220302(00)74985-X

He, Z., Xu, M., Zeng, M., Qin, F., \& Chen, J. (2015). Interactions of milk a - and b -casein with malvidin-3- O -glucoside and their effects on the stability of grape skin anthocyanin extracts. Food Chemistry, 199, 314-322. https://doi.org/10.1016/j.foodchem.2015.12.035

Holt, C., \& Kruif, C. G. (Kees) De. (2003). Casein micelle structure, functions and interactions. In P. F. FOX \& P. L. H. Mcsweeney (Eds.), Advanced Dairy Chemistry (3rd ed.). https://doi.org/10.1007/978-1-4419-8602-3

Horne, D. S. (2009). Casein micelle structure and stability. In: Thompson, A., Boland, M., \& Singh, H (eds). Milk Proteins: From Expression to Food (pp. 133 - 162). San Diego: Elsevier.

Huppertz, T., \& de Kruif, C. G. (2008). Structure and stability of nanogel particles prepared by internal cross-linking of casein micelles. International Dairy Journal, 18(5), 556-565. https://doi.org/10.1016/j.idairyi.2007.10.009

Huppertz, T., Gazi, I., Luyten, H., Nieuwenhuijse, H., Alting, A., \& Schokker, E. (2017). Hydration of casein micelles and caseinates: Implications for casein micelle structure. International dairy journal, 74, 1-11.

Jacob, M., Nöbel, S., Jaros, D., \& Rohm, H. (2011). Food Hydrocolloids Physical properties of acid milk gels: Acidification rate significantly interacts with cross-linking and heat treatment of milk. Food Hydrocolloids, 25(5), 928-934. https://doi.org/10.1016/j.foodhyd.2010.09.003

Jaros, D., Partschefeld, C., Henle, T., \& Rohm, H. (2006). Transglutaminase in dairy products: chemistry, physics, applications. Journal of texture studies, 37(2), 113-155. 
683 Judd, R. C. Electrophoresis of peptides (1994). In: Walker JM (ed.), Methods in 684 molecular Biology, vol. 32, Basic Protein and Peptide Protocols (pp. 49-57). Totowa: Humana Press Inc.

686

687

688

689

690

691

692

693

694

695

696

697

698

699

700

701

702

703

704

705

706

707

708

709

710

Khodaverdi, E., Maftouhian, S., Aliabadi, A., Hassanzadeh-Khayyat, M., Mohammadpour, F., Khameneh, B., \& Hadizadeh, F. (2018). Casein-based hydrogel carrying insulin: preparation, in vitro evaluation and in vivo assessment. Journal of Pharmaceutical Investigation, 1-7.

Klement, W., Lord, H., \& Parker, R. (1960). Hydrophilic Gels for Biological Use. Nature, 188, 929-930.

Lang, Y., Gao, H., Tian, J., Shu, C., Sun, R., Li, B., \& Meng, X. (2019). Protective effects of $\alpha$-casein or $\beta$-casein on the stability and antioxidant capacity of blueberry anthocyanins and their interaction mechanism. LWT, 115, 108434.

Larrauri, J. A., Rupérez, P., \& Saura-Calixto, F. (1997). Effect of Drying Temperature on the Stability of Polyphenols and Antioxidant Activity of Red Grape Pomace Peels. Journal of Agricultural and Food Chemistry, 45(4), 1390-1393. https://doi.org/10.1021/ff960282f

Lee, J., Durst, R. W., \& Wrolstad, R. E. (2005). Determination of total monomeric anthocyanin pigment content of fruit juices, beverages, natural colorants, and wines by the $\mathrm{pH}$ differential method: collaborative study. Journal of AOAC international, 88(5), 1269-1278.

Lee, J., Rennaker, C., \& Wrolstad, R. E. (2008). Correlation of two anthocyanin quantification methods: HPLC and spectrophotometric methods. Food Chemistry, 110(3),

782-786. https://doi.org/10.1016/j.foodchem.2008.03.010

Lee, W. J., \& Lucey, J. A. (2004). Structure and physical properties of yogurt gels: effect of inoculation rate and incubation temperature. Journal of Dairy Science, 87, 3153-3164. 
711 Li, N. N., Fu, C. P., \& Zhang, L. M. (2014). Using casein and oxidized hyaluronic acid to form biocompatible composite hydrogels for controlled drug release. Materials Science and Engineering C, 36(1), 287-293.

Loewen, A., Chan, B., \& Li-Chan, E. C. (2018). Optimization of vitamins A and D3 loading in re-assembled casein micelles and effect of loading on stability of vitamin D3 during storage. Food chemistry, 240, 472-481.

Lucey, J. A (2009). Milk protein gels. In: Thompson, A., Boland, M., \& Singh, H (eds). Milk Proteins: From Expression to Food (pp. 458 - 464). San Diego: Elsevier.

Lucey, J. A. (2017). Formation, structural properties, and rheology of acidcoagulated milk gels. In: McSweeney, P. L. H., Fox, P. F., Cotter, P. D., Everett, D. W. (eds). Cheese: Chemistry, physics \& microbiology (pp. 179 197). London: Elsevier Academic Press.

Lucey, J. A., \& Horne, D. S. (2018). Perspectives on casein interactions. International Dairy Journal, 85, 56-65.

Ma, J., Lee, J., Han, S. S., Oh, K. H., Nam, K. T., \& Sun, J.-Y. (2016). Highly Stretchable and Notch-Insensitive Hydrogel Based on Polyacrylamide and Milk Protein. ACS Applied Materials \& Interfaces, 8(43), 29220-29226. https://doi.org/10.1021/acsami.6b10912

Migneault, I., Dartiguenave, C., Bertrand, M. J., \& Waldron, K. C. (2004). Glutaraldehyde: Behavior in aqueous solution, reaction with proteins, and application to enzyme crosslinking. BioTechniques, 37(5), 790-802.

Moura, M. H. C., Cunha, M. G., Alezandro, M. R., \& Genovese, M. I. (2018). Phenolic-rich jaboticaba (Plinia jaboticaba (Vell.) Berg) extracts prevent high-fat-sucrose diet-induced obesity in C57BL/6 mice. Food Research International, 107, 48-60. https://doi.org/10.1016/j.foodres.2018.01.071 
737 Nayak, S., \& Andrew Lyon, L. (2005). Soft nanotechnology with soft nanoparticles. Angewandte Chemie - International Edition, 44(47), 76867708. https://doi.org/10.1002/anie.200501321

740

741

Nogueira, M. H., Tavares, G. M., Silva, N. F. N., Casanova, F., Stringheta, P. C., Gaucheron, F., ... \& Carvalho, A. F. (2019). Physico-chemical stability of casein micelles cross-linked by transglutaminase as a function of acidic pH. Food Structure, 19, 100103.

Ozel, B., Cikrikci, S., Aydin, O., \& Oztop, M. H. (2017). Polysaccharide blended whey protein isolate-(WPI) hydrogels: A physicochemical and controlled release study. Food Hydrocolloids, 71, 35-46. https://doi.org/10.1016/.j.foodhyd.2017.04.031

Pereira, E. P. R., Cavalcanti, R. N., Esmerino, E. A., Silva, R., Guerreiro, L. R. M., Cunha, R. L., ... \& Cruz, A. G. (2016). Effect of incorporation of antioxidants on the chemical, rheological, and sensory properties of probiotic petit suisse cheese. Journal of dairy science, 99(3), 1762-1772.

Raak, N., Rohm, H., \& Jaros, D. (2017). Cross-linking with microbial transglutaminase: Isopeptide bonds and polymer size as drivers for acid casein gel stiffness. International Dairy Journal, 66, 49-55. https://doi.org/10.1016/j.idairyj.2016.10.015

Rocha, J. de C. G., Procópio, F. R., Mendonça, A. C., Vieira, L. M., Perrone, Í. T., Barros, F. A. R. de, \& Stringheta, P. C. (2017). Optimization of ultrasound-assisted extraction of phenolic compounds from jussara (Euterpe edulis M.) and blueberry (Vaccinium myrtillus) fruits. Food Science and Technology, 38(1), 45-53. https://doi.org/10.1590/1678$457 x .36316$

Rohm, H., Ullrich, F., Schmidt, C., Löbner, J., \& Jaros, D. (2014). Gelation of Cross-Linked Casein under Small and Large Shear Strain. Journal of texture studies, 45(2), 130-137. 
Salcedo-Sandoval, L., Cofrades, S., Ruiz-Capillas, C., Matalanis, A., McClements, D. J., Decker, E. A., \& Jiménez-Colmenero, F. (2015). Oxidative stability of $n-3$ fatty acids encapsulated in filled hydrogel particles and of pork meat systems containing them. Food Chemistry, 184, 207-213. https://doi.org/10.1016/j.foodchem.2015.03.093

Schorsch, C., Carrie, H., Clark, A., \& Norton, I. (2000). Cross-linking casein micelles by a microbial transglutaminase conditions for formation of transglutaminase-induced gels. International Dairy Journal, 10(8), 519-528.

Schuck, P., Piot, M., Méjean, S., Le Graet, Y., Fauquant, J., Brulé, G., \& Maubois, J. L. (1994). Déshydratation par atomisation de phosphocaséinate natif obtenu par microfiltration sur membrane. Le lait, 74(5), 375-388.

Silva, N. F. N., Casanova, F., Gaucheron, F., Teixeira, A. V. N. de C., da Silva, G. M., Minim, L. A., \& Carvalho, A. F. de. (2018). Combined effect of transglutaminase and sodium citrate on the microstructure and rheological properties of acid milk gel. Food Hydrocolloids, 82, 304-311. https://doi.org/10.1016/j.foodhyd.2018.03.038

Silva, S., Costa, E. M., Calhau, C., Morais, R. M., \& Pintado, M. E. (2017). Anthocyanin extraction from plant tissues: A review. Critical Reviews in Food Science and Nutrition, 57(14), 3072-3083. https://doi.org/10.1080/10408398.2015.1087963

Smeriglio, A., Barreca, D., Bellocco, E., \& Trombetta, D. (2016). Chemistry, Pharmacology and Health Benefits of Anthocyanins. Phytotherapy Research, 30, 1265-1286.

Smiddy, M. A., Martin, J. G. H., Kelly, A. L., Kruif, C. G. De, \& Huppertz, T. (2006). Stability of Casein Micelles Cross-Linked by Transglutaminase. Journal of Dairy Science, 89(6), 1906-1914. https://doi.org/10.3168/jds.S0022-0302(06)72258-5 
793 Song, F., Zhang, L. M., Shi, J. F., \& Li, N. N. (2010). Novel casein hydrogels:

794

795

796

797

798

799

800

801

802

803

804

805

806

807

808

809

810

811

812

813

814

815

816

817

818

819

820

Song, F., Zhang, L. M., Yang, C., \& Yan, L. (2009). Genipin-crosslinked casein hydrogels for controlled drug delivery. International journal of pharmaceutics, 373(1-2), 41-47.

Sun, J., Ren, F., Chang, Y., Wang, P., Li, Y., Zhang, H., \& Luo, J. (2018). Formation and structural properties of acid-induced casein - agar double networks: Role of gelation sequence. Food Hydrocolloids, 85, 291-298. https://doi.org/10.1016/j.foodhyd.2018.07.030

Sung, H.-W., Huang, R.-N., Huang, L. L. H., \& Tsai, C.-C. (1999). In vitro evaluation of cytotoxicity of a naturally occurring cross-linking reagent for biological tissue fixation. Journal of Biomaterials Science, Polymer Edition, 10(1), 63-78.

Tavares, G. M., Croguennec, T., Carvalho, A. F., \& Bouhallab, S. (2014). Milk proteins as encapsulation devices and delivery vehicles: Applications and trends. Trends in Food Science and Technology, 37(1), 5-20. https://doi.org/10.1016/j.tifs.2014.02.008

Tunick, M. H. (2010). Small-strain dynamic rheology of food protein networks. Journal of Agricultural and Food Chemistry, 59(5), 1481-1486.

Wrolstad, R. E. (2004). Anthocyanin pigments - Bioactivity and coloring properties. Journal of Food Science, 69(5), C419-C421. https://doi.org/10.1111/j.1365-2621.2004.tb10710.x

Walstra, P., Wouters, J. T. M., \& Geurts, T. J. (2006). Dairy Science and Technology (Second Edi., Vol. 4). Taylor \& Francis.

Wei, J., Xu, D., Yang, J., Zhang, X., Mu, T., \& Wang, Q. (2018). Analysis of the interaction mechanism of Anthocyanins (Aronia melanocarpa Elliot) with $\beta$ casein. Food hydrocolloids, 84, 276-281. 
821 Xu, J., Fan, Z., Duan, L., \& Gao, G. (2018). A tough, stretchable, and 822 extensively sticky hydrogel driven by milk protein. Polymer Chemistry, 8239 9(19), 2617-2624. https://doi.org/10.1039/c8py00319j

824 Xu, R., Teng, Z., \& Wang, Q. (2016). Development of tyrosinase-aided 825 crosslinking procedure for stabilizing protein nanoparticles. Food 826 Hydrocolloids, 60, 324-334. https://doi.org/10.1016/j.foodhyd.2016.04.009

827 Zhang, Z., Decker, E. A., \& McClements, D. J. (2014). Encapsulation, 828 protection, and release of polyunsaturated lipids using biopolymer-based 829 hydrogel particles. Food Research International, 64, 520-526. https://doi.org/10.1016/j.foodres.2014.07.020 
Table 1. Treatment designation.

\begin{tabular}{|c|c|c|c|c|}
\hline & A & B & C & $\mathrm{D}$ \\
\hline Transglutaminase $(\mathrm{u} / \mathrm{g})$ & - & 3 & - & 3 \\
\hline Jaboticaba extract (\%) & - & - & 2 & 2 \\
\hline Glucono - $\delta$ - lactone (\%) & 2 & 2 & 2 & 2 \\
\hline
\end{tabular}


Table 2. Hydrodynamic diameter and $\zeta$-potential of casein micelles.

$\begin{array}{llll}\text { A } & \text { B } & \text { C }\end{array}$

Hydrodynamic diameter $(\mathrm{nm}) \quad 174.3 \pm 5.5^{\mathrm{a}} \quad 161.4 \pm 1.6^{\mathrm{b}} \quad 177.2 \pm 5.2^{\mathrm{a}} \quad 160.2 \pm 1.5^{\mathrm{b}}$

$\zeta$-potential $(\mathrm{mV}) \quad-12.8 \pm 0.1^{\mathrm{a}} \quad-12.7 \pm 0.2^{\mathrm{a}} \quad-12.8 \pm 0.1^{\mathrm{a}} \quad-12.5 \pm 0.1^{\mathrm{a}}$

Means followed by the same letter in the lines do not differ significantly $(p>0.05)$ according to Tukey's HSD test. A Casein micelles without transglutaminase or jaboticaba extract, B Casein micelles with transglutaminase but without jaboticaba extract, C Casein micelles without transglutaminase but with jaboticaba extract, D Casein micelles with transglutaminase and jaboticaba extract. 


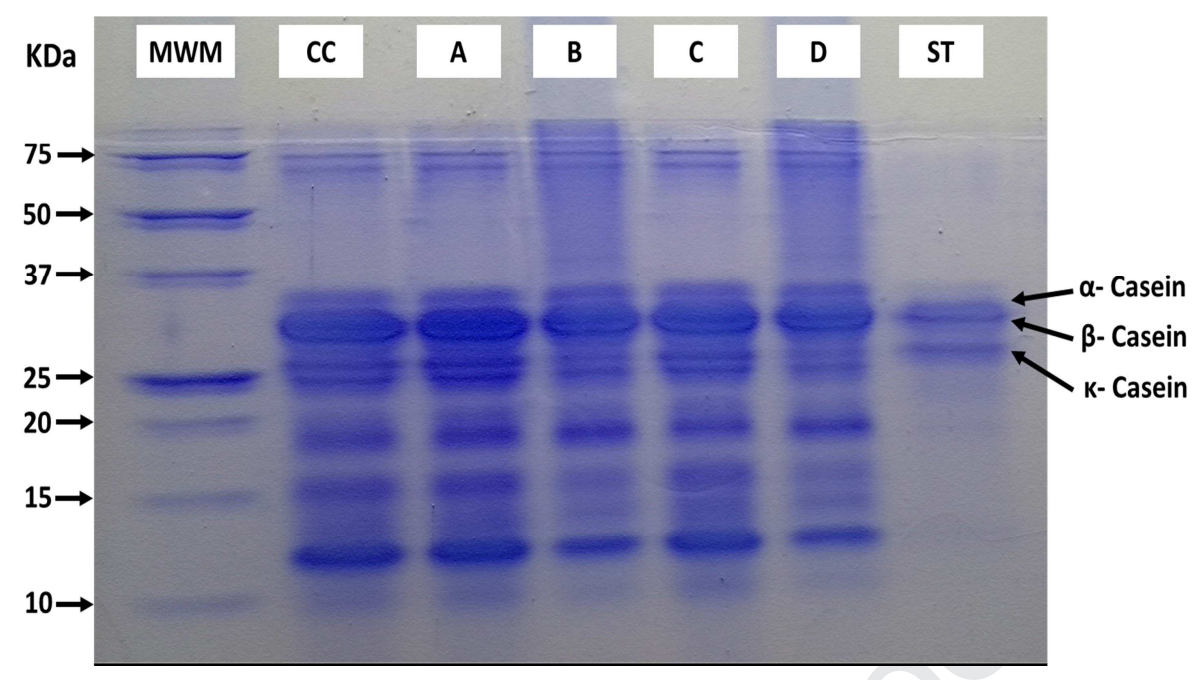

Figure 1. SDS-PAGE electrophoresis images of four samples showing molecular weight markers and casein fraction standards. MWM: Molecular weight marker; CC: Casein dispersion before any treatment; A Casein micelles without transglutaminase or jaboticaba extract, B Casein micelles with transglutaminase but without jaboticaba extract, C Casein micelles without transglutaminase but with jaboticaba extract, D Casein micelles with transglutaminase and jaboticaba extract. 


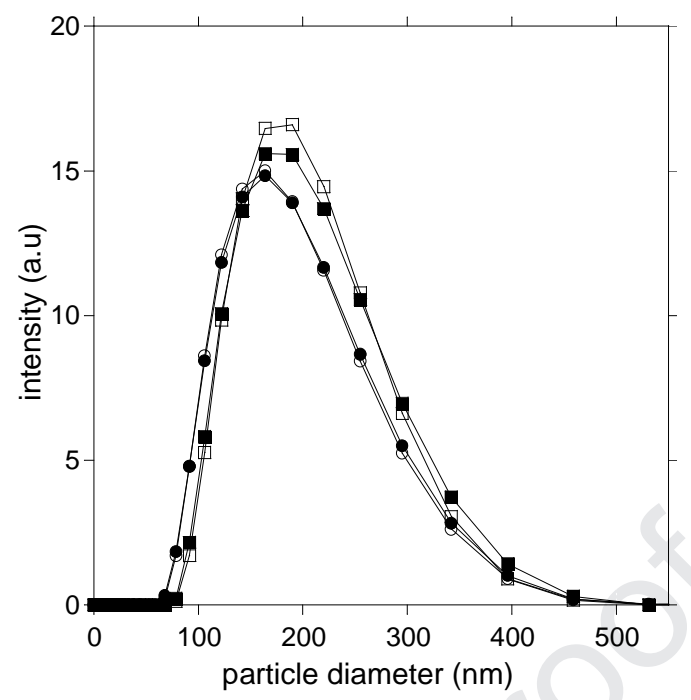

Figure 2. Intensity (a.u.) as a function of particle diameter $(\mathrm{nm})$ obtained by DLS measurement of each suspension. A (), B (०), C (•), D (•). 


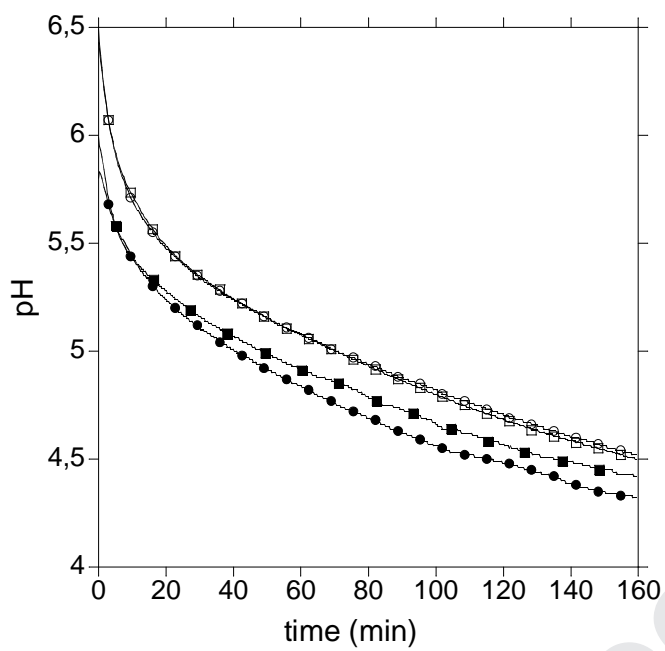

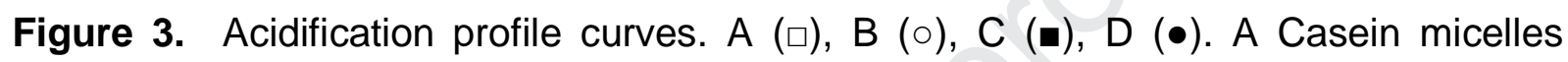
without transglutaminase or jaboticaba extract, B Casein micelles with transglutaminase but without jaboticaba extract, C Casein micelles without transglutaminase but with jaboticaba extract, D Casein micelles with transglutaminase and jaboticaba extract. 

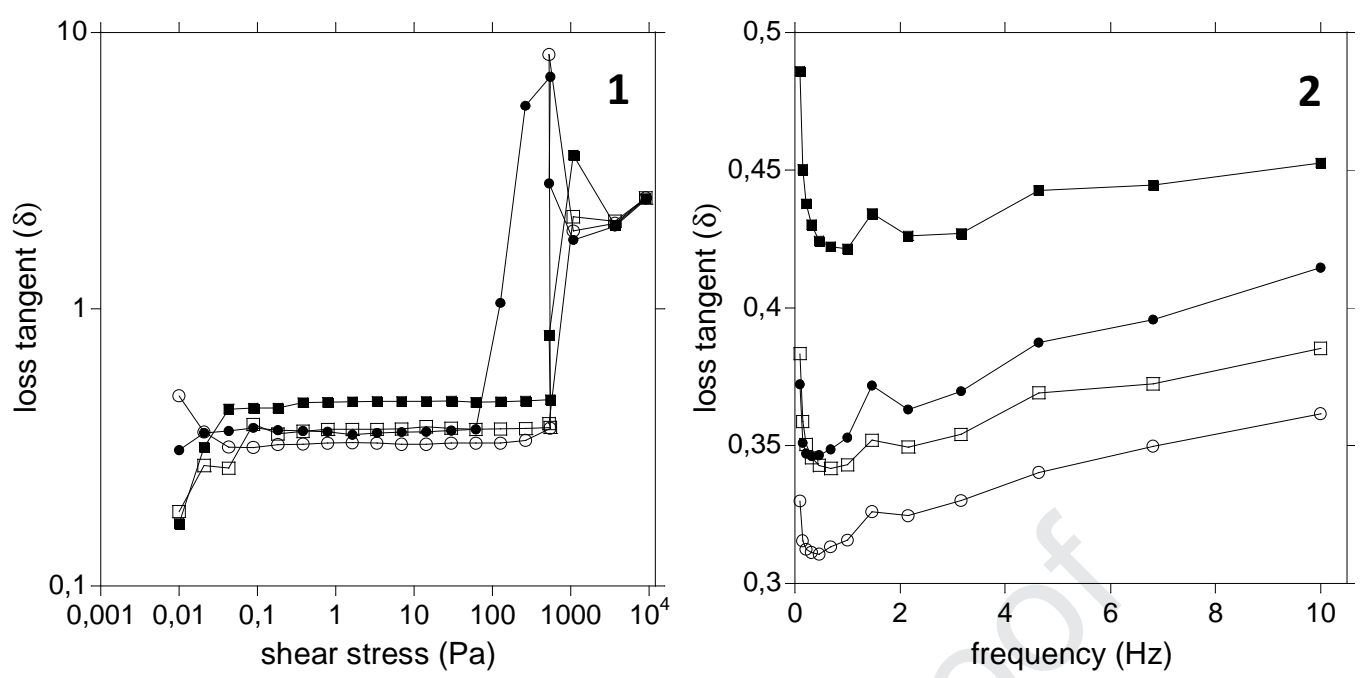

Figure 4. (1) Shear stress sweep of the four hydrogel samples. (2) Frequency sweep of the four hydrogel samples. Samples designation: Casein micelles without transglutaminase or jaboticaba extract (口), Casein micelles with transglutaminase but without jaboticaba extract (०), Casein micelles without transglutaminase but with jaboticaba extract $(\mathbf{\bullet})$, Casein micelles with transglutaminase and jaboticaba extract $(\bullet)$. 

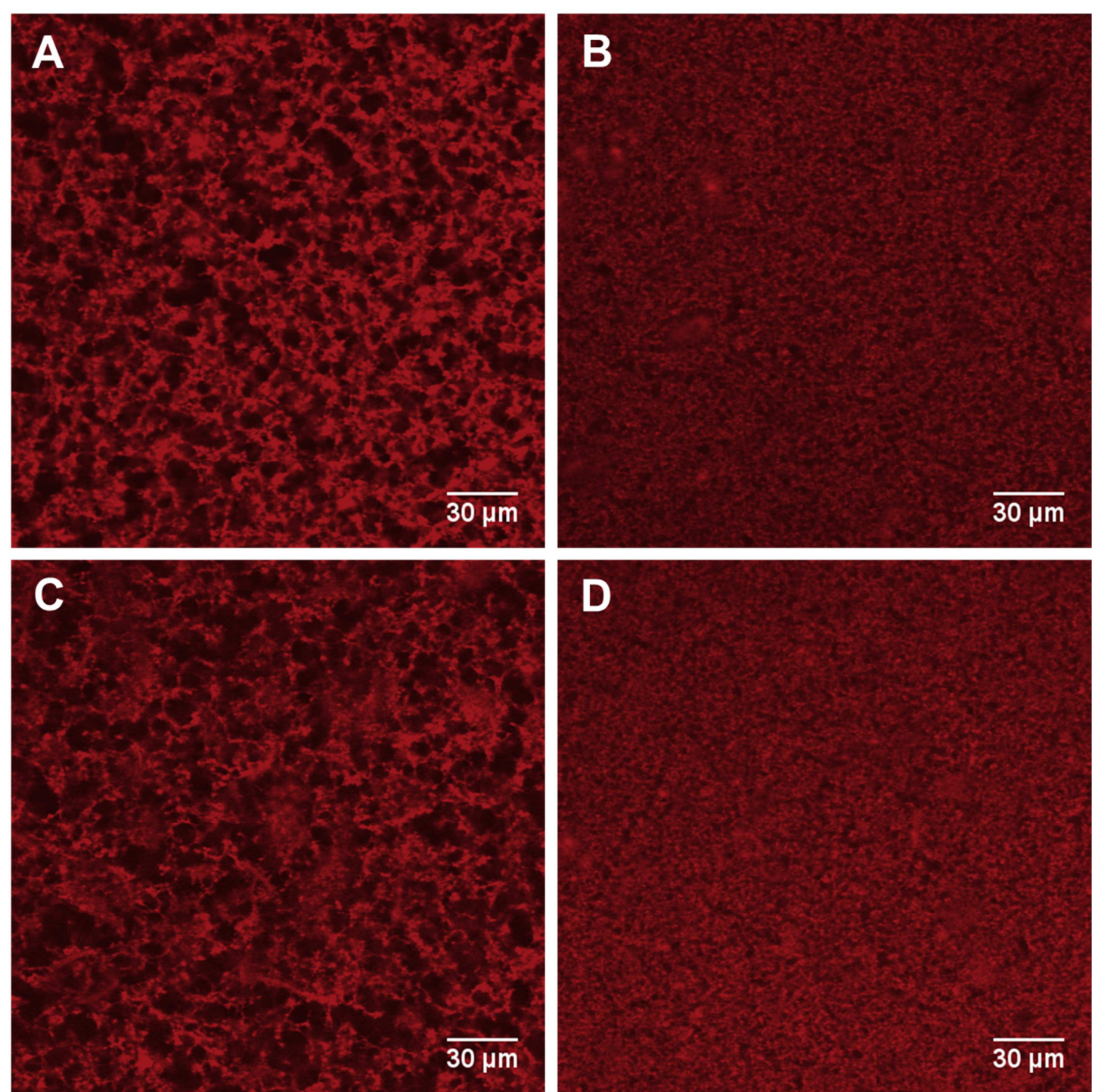

Figure 5. Confocal scanning laser images of casein hydrogel samples. A Casein micelles without transglutaminase or jaboticaba extract, B Casein micelles with transglutaminase but without jaboticaba extract, $C$ Casein micelles without transglutaminase but with jaboticaba extract, D Casein micelles with transglutaminase and jaboticaba extract. 

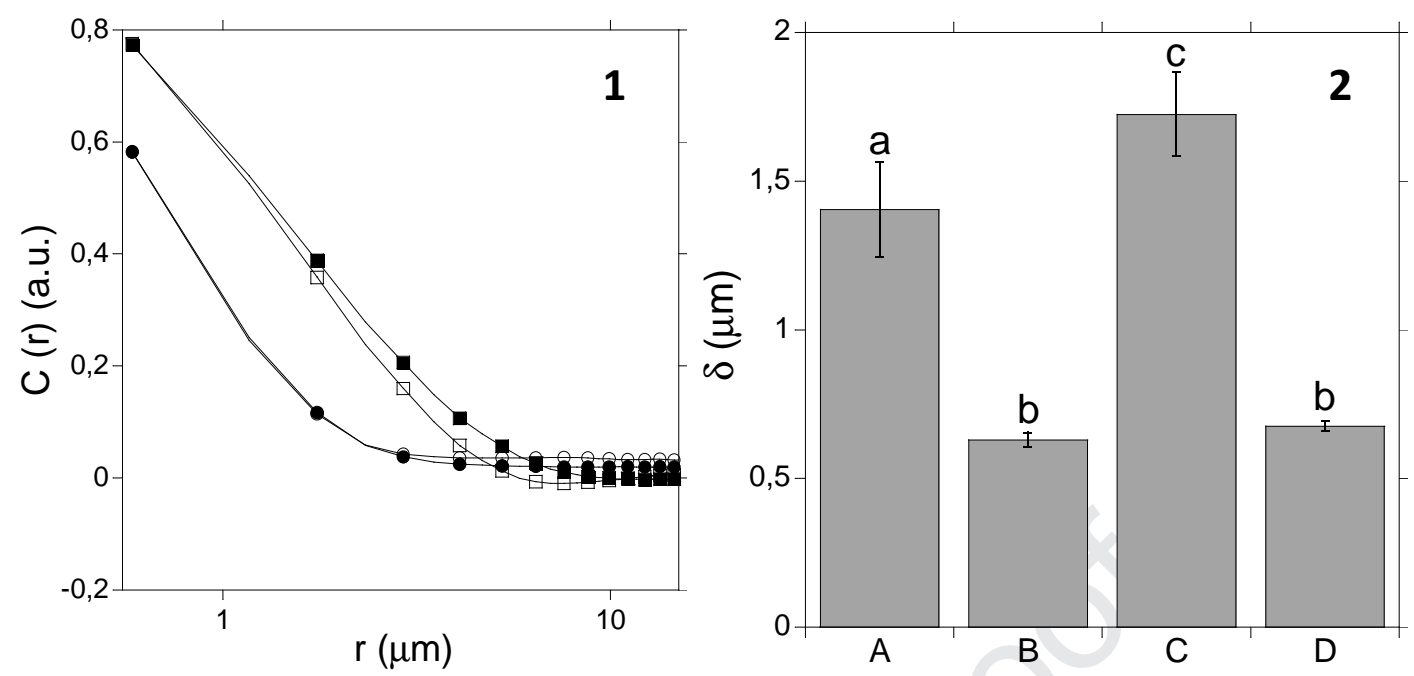

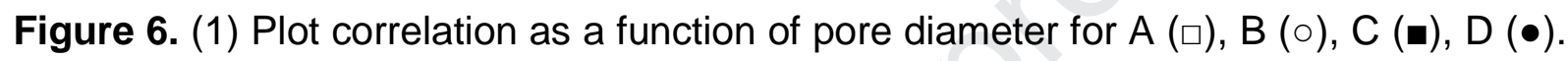
The lines are determined by simple exponential decay. (2) Hydrogel sample mean pore size $(\mu \mathrm{m})$. Different lower-case letters at the top of the columns indicate $5 \%$ difference in the significance level as determined by Tukey HSD test. Samples designation: Casein micelles without transglutaminase or jaboticaba extract ( $\square$ ), Casein micelles with transglutaminase but without jaboticaba extract (०), Casein micelles without transglutaminase but with jaboticaba extract (-), Casein micelles with transglutaminase and jaboticaba extract $(\bullet)$. 

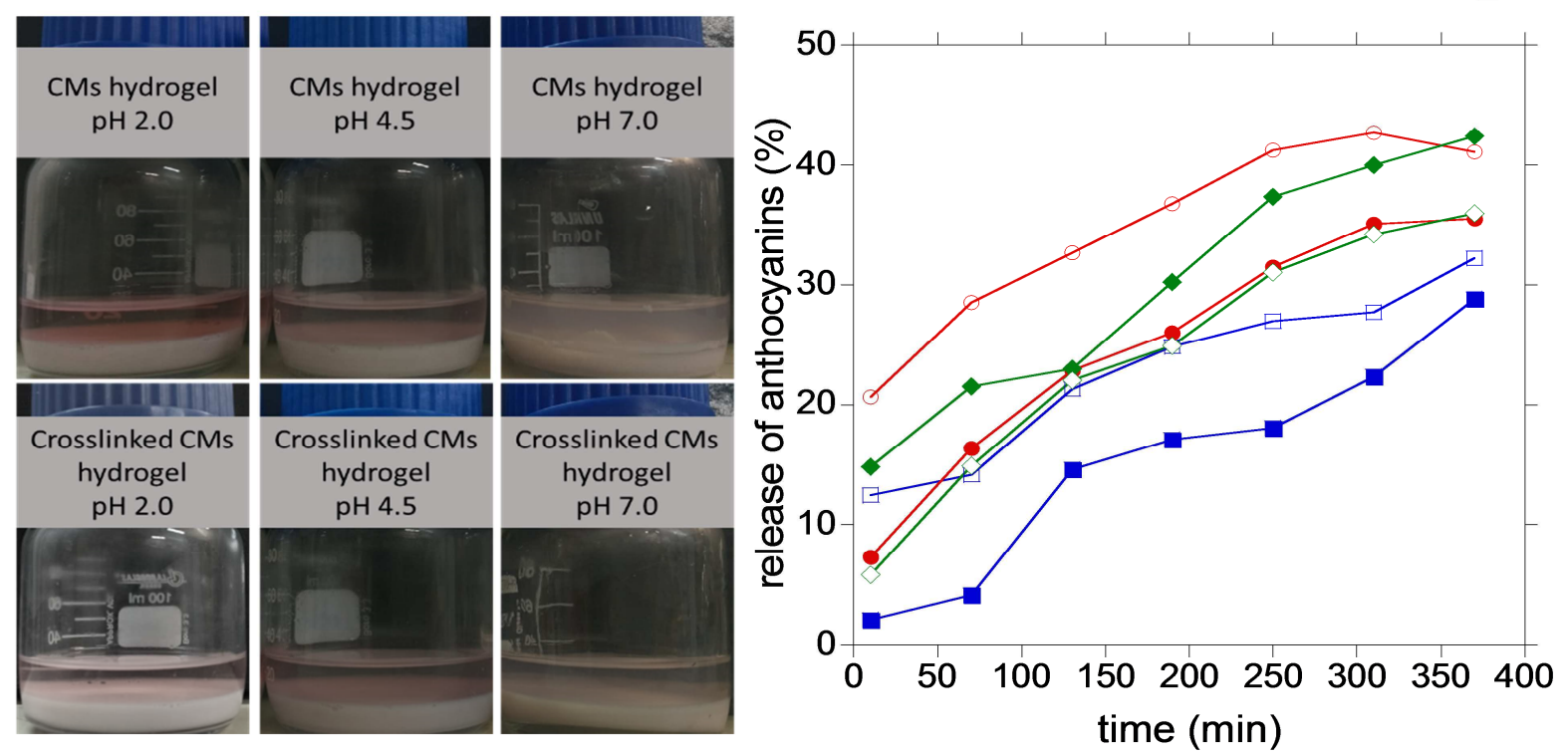

Figure 7. (1) On the left: shot flasks containing casein hydrogels in different $\mathrm{pH}$ conditions. (2) anthocyanin release profile of crosslinked, sample D (full symbols) and non-crosslinked, sample $\mathrm{C}$ (empty symbols) hydrogels at $\mathrm{pH} 2.0\left(\boldsymbol{\square}^{\circ}\right), 4.5(\bullet \circ)$ and 7.0 $(\diamond)$. 


\section{Highlights}

- Casein hydrogels can be used to carry and delivery anthocyanins from jaboticaba fruit (Myrciaria cauliflora).

- The rate of release can be modulated by the presence of transglutaminase.

- Maximum release was observed at $\mathrm{pH} 7.0$ whereas minimum at $\mathrm{pH}$ 2.0. 


\section{Conflict of interest}

The authors declare that there are no conflicts of interest. 